\title{
Animation in Transition: A Semiotic Reading of Ase Mmanwu Masquerade Costume in Performance.
}

\author{
Julie Umukoro \\ Department of Theatre and Film Studies \\ University of Port Harcourt. Port Harcourt.
}

\begin{abstract}
The study takes a critical look at costume in motion. Motion or movement here imposes on costume the image of a living object and as such a composition drawn on a symbiotic relationship between an article of material culture and an animator; usually a human factor. This thus infers that, it is in the conjugal relationship of performer and costume that the performance-costume attains full realization and finally, a scaling up in its utility value. The study addresses critically, the Ase Mmanwu costume in performance. As tool to aid artistic exhibition, the Mmanwu costume in performance comes alive as a rich semiotic field explored for signification in the Ase Mmanwu art. The brand, embodied in spatial movements and convolutions, creates and imposes strictly the image of an animated and highly reflexive object which lingers in the consciousness of its beholder(s) long after its perception. With special interest in the masking components of Ase Mmanwu tradition,

this discourse is restricted to the animated and antiquated costume of the Mmanwu masquerade of Ase people of Nigeria.
\end{abstract}

Keywords: African, Performance, Masquerade, Costume, Animation.

\section{INTRODUCTION}

Guided by a deep-seated attachment to African pristine norms, the African has developed a psyche that prompts him to identify with the pervasive features of his society. Thus he pays glowing tributes to his African roots through characteristic African performance forms, colorfully animated by verbal, visual and aural antecedents. The proliferation of artistic performance forms in African societies is usually traced to the African's celebrative spirit and indeed, his penchant to commemorate his various experiences in outward shows of conviviality. African performances come in a great many varieties, and differ from one another in form, content, purpose and magnitude. They are variously constituted and grouped, with brands ranging from the serious to the unserious. They may be commemorative or merely serve social needs of recreation. Thus, there are celebrative performances for designated festivals, masquerade cults and for ritual or religious rites such as funerary rites of passage or initiation and even royalty rites. There are also several other social forms, less formalised or stylised than the first and are used on occasions such as chieftaincy, circumcision, marriage, child-birth and child-naming ceremonies. On the other hand, there are types that are not too dogmatic and less formalised. Typical examples are revues, carnivals, and communal fairs employing loosely dance, music and acrobatic displays for engagement and entertainment. These can operate in both formal and informal settings and may accommodate innovations All in all, in a spectacular and vivacious manner, African performances exhibit in a robust fashion, attributes of Africanness by which they are constantly distinguished or recognized.

\section{Festivals and Social Performances of Ase People (Nigeria)}

Ase, often referred to as Ase-Ebeneze in honour of its founder, Ebeneze, came into existence at about 1456. The Ase Kingdom, covering Ase main town, Iwene, Asaba-Ase, Iwure-Ugboko, 
Egbeme, as well as the fishing ports around Ekregbeesi, is located in the present day Delta State of Nigeria. It is bounded on the East by the River Niger, on the West by the Isoko communities, on the North by Ibedeni and on the South by Ijaw communities. Ase main town however, is the seat of the Igwe (King) of Ase, a descendant of the Umu-Ogwuezi Royal House of Umuonotu; hence, the centre of all festive activities of the clan. For administrative ease, the Ase clan is divided into six distinct areas or quarters as they are known. Each of these quarters - Umuonotu, Echei, Ogbonome, Ekukeni, Asaba-Ase and Egbeme - has a chief designated to oversee it on behalf of the Igwe. Thus, there is the Aguenya of Echei, the Eje of Ogbonome, the Onou of Ekukeni, the Onise of Asaba-Ase and the Ochonor of Egbeme. These, alongside several other palace chiefs, make up the Royal administrative caucus led by the Igwe himself. The main festival observed by the Ase people is Erishi Festival.

\section{Erishi Festival}

The Erishi festival has remained the most significant of Ase festivals. Not only did it denote the climax of one harvesting season, it ushered in the new season with rites, pomp and pageantry. Significantly, Erishi festival, for the Ase citizenry, was not just fanfare but one dynamic social cohesive force with which stability, peace and human relations was maintained. Thus, besides being a reason for expiation, it was a season for supplication to man and the gods for wrongs or rights, as the case might be. The festival thus in multiple dimensions appealed to the collective consciousness of the people and indeed prodded a determination toward oneness and peaceful coexistence. Unlike other festivals of Ase, the Erishi Festival, was under the sole jurisdiction of the Igwe (King) and it was his prerogative to give approval for its celebration annually. Others, were mini festivals, and indeed the sole affairs of individual Quarters to which they belonged. However, for communal authenticity, approval had to be given first by the king; a mandate which enabled the Eze-Egwu (Dance-Chief), the dance maestro of the community, to team up with the Quarter Chief to organize it. Though performances were restricted to the celebrating party, mini Quarter festivals remained a communal celebration as Quarters not directly involved played participatory roles as audience to the performing group.

At the appointed time for the Erishi Festival, the Igwe summoned the Eze-Egwu (Dance-Chief) and empowered him to fix its celebration and as well as send words round the community to advertise it. Each Quarter was expected to field performances. The activities, usually at the market square, involved the entire members of the clan and lasted for a period of one week. Performers included Ekeneke the stilt dancers, the colourfully costumed Ekuwusie-Ododo, with their imposing head-gears as well as the egwu-isha and egwu-amara-buyo. Dance apart, performances included masquerade and acrobatic displays. With the expertise of the Uffie drummers and the rhythmic music from the percussive tamgbi setting the mood, performers exhibited well-rehearsed and intricate dance movements to the thrill of the audience. The most popular masquerades at the Erishi festival were the aggressive Anyangba, the Ogoni, the Owo, and the Mmanwu.

\section{Ase Masked Performances: Mmanwu Masquerade in Focus}

Mask performances were rife among Ase people. This was so because of their common belief in the manifestation of dead ancestors through masquerades. The masquerade was thus a symbolic entertainment art form. It had from time immemorial served as a cultural signpost or icon denoting that invisible animating or energizing force the Ase people often referred to as Nmo (spirit). This line of thought is validated in the views of a number of scholars of Anthropology or Cultural Studies as indicated in the references: "ancestral character" "ancestral manifestation" "ancestral spirit", "incarnate beings" "spirit being" (Henry Drewal 1974, Ojo, 1974 Okoye, 2007:60, Ododo, 2010:206, Dugga, 2010:219,) The Mmanwu's outing, 
according to the common belief of Ase people, presupposes the presence of an ancestral spirit, "credited with supernatural powers and supernal insights". They were said to visit their "erstwhile communities, at the ordinance of their members, to celebrate or mourn with them, or dispatch some social actions of consequence" (Okoye, qtd in Ododo, 2010: 206). Thus, in Ase cosmology, death becomes the medium by which the spirit of the dead is transposed into a higher being; a god or goddess or Nmo in the local parlance and who, by supernatural, means is conjured to visit the living through some designated mediums as reported by Robin Horton in "The Gods as Guests: An Aspect of Kalabari Religious Life"(Horton, in Ogunbiyi, 2014:98-137) The Masquerade device has been identified as one such medium by which the Kalabari people (Nigeria) communed with their ancestors. As with the Kalabari ethnic group, Ase people of Nigeria are also noted for their use of the masquerade medium as interface between the world of the living and the living-dead i.e. the world of the ancestral spirits. Conjured, the manifestation of the spirit is effected by its consummation with the designated costume designed for its purpose and which as a consequence becomes transmogrified. This transmogrification is exhibited in performance through a vibrancy which is associated with this spiritual incarnation. Against the paradoxical image of the living-dead, the ancestral figure takes on an oracular image. Built on the cognate relationship between man as a living being and man as a reincarnated being, it toes the path of mystery. Its conventions are enmeshed in secrecy open only to insiders bound by oath never to let them out to the ogbodi (non-initiates). The institution thus is well guarded by taboos and sanctions socially and culturally endorsed by its society. The Mmanwu masquerade, is perceived and conceived in a clothing idiom and manifests its being in an automated voluminous robe crystallized in kinesthetic motion. In relation to its composite structure, form, features and configuration, the Mmanwu masquerade of Ase is style-specific in every respect. This is so because it is specially guided by conventions and taboos sacrosanct and germane to its cult.

Although this research exercise is limited to the Mmanwu pedigree, it is pertinent to note that there are quite a number of other kinds of masquerades found among Ase people. They include: Ogbo-oyibo, Okpotu, Orikpo, Eze-nmo, Oje, Uridi, Ene and Ozo. Given the central focus of this study concerned with costume as animation in transition, the researcher critically examines, from a visual aesthetic position, the Mmanwu masquerade phenonenon of Ase people. Beyond its appeal as a mobile branded anthropomorphized object of material culture the Mmanwu masquerade costume is appraised as a construct with a duality of purpose; serving not only as dress but also as physical body to the ancestral spirit which we can only perceive in the subconscious. It is this latter concept that imposes the supernatural as well as the sacrosanct image with which all Mmanwu artifacts are appraised. Given these varying points of view, signification assumes a multi-dimensional and multileveled interpretation. Therefore, this 'covering' the 'outer-layer' that the ordinary eye can perceive takes on different meanings to different perceivers. The mystified and invisible masker's paramount place is to provide the Mmanwu costume with its energizing force and thus conditionally aids its transposition from the image of non-living to living. Basically, the study, against the backdrop of human kinetics and animation, relates to aspects of physical movement, and the illusion of unbroken movement by which the costume is characterized to play its peculiar traditional role(s). Because of his significant role of revivification, the masker stands as the soul of the Mmanwu itself. From another perspective, the Mmanwu may sometimes be seen as the spirit of the dead and as such, the masker may connote the invisible spirit of a dead ancestor for whom the masker serves as medium. Thus the masker acquires the esoteric image sustained in a hidden identity; unknown however, only to outsiders (non-initiates). Cast therefore in the image of the invisible (spirit) - a nonentity - the masker's persona is completely subsumed by 
the peculiar clothing idiom that anthropomorphizes the Mmanwu phenomenon. The masker, while serving its purpose as the energizing force in its animation, transposes the costumemask from being a mass of inanimate material culture to a living object appraised by its transitory convolutions in movement and dance. Thus, such successive convolutions of the dress-piece in a continuous stream simulates the illusion of unbroken movement - animation. This then creates varying pictorial images in movements which invariably continue to linger in the sub-conscious realm of a beholder long after their perception. This is corroborated by Peter Mark Roget's notion that the retina of the human eye retains images for a while before they are replaced by succeeding ones. This study posits therefore, that the Mmanwu masquerade is a costume-mask art built on the framework of performance. More than a mere disguise technique, the Mmanwu costume metaphor is a design composition that supposedly derives its significance only through performance; and this by a symbiotic relationship between the specified articles of material culture (costume/accessories) and the energizing force (spirit/masker/performer). It follows therefore that it is only by such connubial relationship of costume and masker, and always within a performance structure, that the Mmanwu masquerade costume is accorded its full complement.

\section{The Image of Ase Mmanwu Masquerade as Costume Par-excellence}

The Ase Mmanwu Masquerade costume is a mass of brownish raffia strips built into a conicalshaped gown covering which, from the upper part (head) spreads out toward the lower level (feet). The conical costume which is usually double the average human height, ends with a rich tuft of wigs. The torso, decorated with red fluffy wool strings and strips of red velvet material for aesthetics, also has small oval mirrors and Indian bells affixed. These stripes of velvet which hang loosely from the torso downwards sway harmoniously to the Mmanwu's magnificent movements while his presence is visually and aurally highlighted by the sparkles of the mirrors and the jangle or clatter of the Indian-bells fixed generously about it. With a strange guttural but sonorous voice to cap it all, everything merge in a holistic synergy that produces in the Ase Mmanwu masquerade the awe-inspiring aura that forever hovers about its personality. The Ase Mmanwu masquerade costume carries an opposing binary image of life and death to the initiate and non-initiate alike. The costume, synonymous with the dead, metamorphoses in performance assuming the image of the living-dead. That is to say, in performance, the dead resurrects through costume animation. Thus, the represented spiritbeing has the attribute of life imposed on its image; the costume serving at once as both spiritbody and spirit-dress. That masquerade costumes often portend the image of death is corroborated in Soyinka's Death and the King's Horseman in which the character, Amusa describes the Egungun masquerade costume as "uniform of death" (Soyinka, 1982: 25).

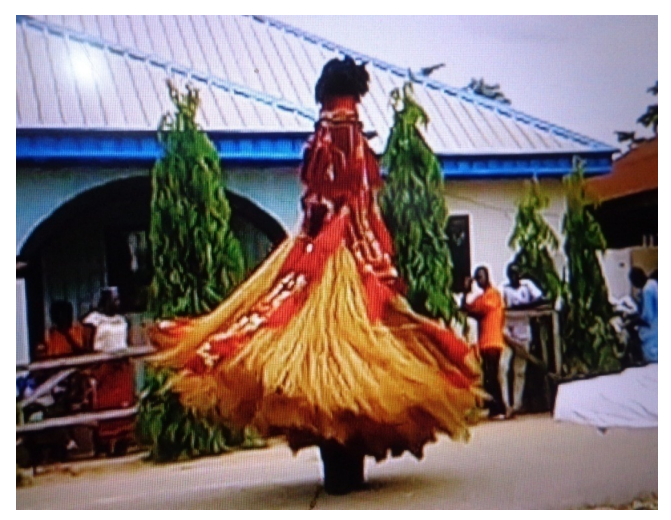

ASE MMANWU MASQUERADE

Photo by Gogo Gladys Oriekeme on Ase Day, April 2013 
As both body and dress, it serves not only as 'casing' or aesthetic covering for the invisible spirit, but very much the personification of the spirit itself. In this dual capacity the Mmanwu costume, by its esoteric and aesthetic value, commands respect and veneration. Thus, it is in a synthesis of its intricate dance and costume movements, alongside its peculiar rhythmic drumming, that the Ase Mmanwu Masquerade's aesthetic value, and/or transmogrifying essence can be fully appreciated.

From a theatrical perspective, the Ase Mmanwu phenomenon is performance oriented. The dance art adopts a fluid structure; however, there are accompanying characters with functionspecific roles delineated by the Mmanwu art itself. Characters include the flag bearer, the whip bearer and the interpreter. Although the Mmanwu, being the central figure, steals the show ever so often, the drummers, in a synergy of drumming and frenzied body movements play allied complementary roles. That is to say, all members sing, clap and dance to the rhythm of the drums alongside the Mmanwu who, however, remains the star performer. Under the spell of the magical mood created by the Mmanwu costume, the adept dancer, indeed the enlivening spirit behind the art, sits atop of his game, impersonating the spirit-being with remarkable vivacity.

\section{References}

Dugga, Victom Samson (2010) "From Lagbaja: Mask, Music and the reinvention of Africa: A Transition" in Culture, Identity and Leadership in Nigeria by Dandaura, Emmanuel Samu and AbdulRasheed Abiodun Adeoye. Society of Nigerian Theatre Artists.

Dandaura, Emmanuel Samu et al. (2010) Culture, Identity and Leadership in Nigeria (eds.) Society of Nigerian Theatre Artist.

Horton, Robin. “The Gods as Guests: An Aspect of Kalabari Religious Life” in Drama and Theatre in Nigeria: A Critical Source Book, edited by Yemi Ogunbiyi. Published by Tanus Books Ltd., Lagos: Nigeria.

Ododo, Sunday Enessi. (2010) “From Masquerade to 'Facekuerade': A Transition” in Culture, Identity and Leadership in Nigeria by Dandaura, Emmanuel Samu and AbdulRasheed Abiodun Adeoye. (eds.) Society of Nigerian Theatre Artists.

Ogunbiyi, Yemi (ed.) (2014) Drama and Theatre in Nigeria: A Critical Source Book. Tanus Books Ltd., Lagos: Nigeria.

Soyinka, Wole. (1982) Death and the King's Horseman. Methuen: London. 